The Eastern Librarian, Volume 23(1), 2012, ISSN: 1021-3643 (Print). Pages: 24-36. Available Online: http://www.banglajol.info/index.php/EL

\title{
THE DETERMINATION OF VALUE IN ARCHIVAL SCIENCE AND THE EVER EVOLVING THEORIES OF RECORDS SELECTION
}

\author{
Lekoko Kenosi, $\mathrm{PhD}$ \\ University of Botswana, Botswana. \\ E-mail: lekoko.kenosi@gmail.com \\ Trevor Moatlhodi \\ University of Botswana, Botswana.
}

\begin{abstract}
The task of purging some records and retaining others for long term preservation in an archival repository has not been an easy one for records professionals. This task is even made more difficult by the fact that what is destroyed as useless by today's standards can prove to be of invaluable use tomorrow. Ideally, archivists would want to keep everything to avoid such errors of judgment. However, the reality of limited storage facilities and the rate at which records are generated makes it impossible to preserve each and every record produced. This paper, co- authored by a graduate student and his mentor, discusses theories of records selection to help shape the difficult decisions of "to keep" and "what to eliminate" in an archival repository.
\end{abstract}

DOI: http://dx.doi.org/10.3329/el.v23i1.12116

KEYWORDS

Archival Science, Records Selection, Taxonomy of Records Appraisal.

\section{INTRODUCTION}

The determination of value, or Appraisal, is one of the most controversial topics in archival discourse. The University of British Columbia (2003) defines appraisal as "the process of evaluating documents for the purpose of continuing preservation." The history of the archival profession, from antiquity to the present moment, reflects appraisal as a key function of archivists. The main objectives of appraisal are to select records (with enduring value) for permanent

24 The Eastern Librarian-peer-reviewed journal in LIS since 1965 
preservation and those that are identified as ephemeral for destruction. Yiotis (2005, p.1) notes that "appraisal is done in order to determine which institutional activities create records that provide a true image of society". During appraisal, Archivists and Records managers are mainly encouraged to look for, and preserve information and evidence relating to the organization and the records of its core functions (Ramokate \& Moatlhodi 2010, p.69). According to Schellenberg (1956), records of an organization or government body that produce them, and the information they contain relating to persons, corporate bodies, conditions, problems and issues it dealt with are a source of evidence which ought to be identified during appraisal. After appraisal, the records with enduring value undergo a process of arrangement and description (to provide intellectual control) then get preserved permanently in the archives for the sake of providing future generations with an image of society as it really is but not necessarily as conceived by those producing the records. The function of public records and archives is to protect rights of citizens, ensure accountability of elected representatives (government), to provide reference services for research and to facilitate administrative processes (Ramokate and Moatlhodi 2010, p. 68). Menne-Haritz (1997, p.3) concurs that archives play a part in assuring political and administrative transparency in democratic societies.

However, it should be noted that records appraisal is not an easy as said. There is no perfect formula or approach to appraisal and as a result there are always opportunities of mistakes in the exercise especially that it is done by more than one person. Ramokate and Moatlhodi (2010, p.68) concur that appraisal is a challenge itself as it requires decision making on whether to preserve or destroy records and there is no clear-cut formula for the process. As observed by Schellenberg (1956, p.24), records pertaining to implementation of government programs are difficult to manage in the archival context especially because they present a major challenge of evaluation. Daniels (1988, p.53) concurs that appraisal is often difficult as any materials could be of some use to one researcher or another in future, therefore presenting an argument for keeping everything. In this regard, Archivists and Records Managers are challenged in determining the 'fate' of recorded information, which results in 'hits and misses' during appraisal. Nevertheless, appraisal has to be done as we cannot keep everything forever. Nicol (1992, p.39) points out that if we do not appraise and destroy some records "we would be buried beneath a mould of paper", which will present challenges of capacity in terms of storage space, human resource and equipment. 
Lack of a perfect formula has over the years also resulted in emergence of differing schools of thought on the approach to appraisal of records. These schools are the European School, The American School, The German School, Macro Appraisal and The Documentation Strategy. A critical discussion will be drawn from these 4 appraisal ideologies by bringing up the positives and limitations of each.

\section{THE EUROPEAN TAXONOMY OF RECORDS APPRAISAL}

This school of thought was led by Sir Hillary Jenkinson who was the Deputy Keeper at the Public Record Office (UK National Archives) from 1947 to 1954 (Honer \& Graham 2001, p. 384). In his best-known publication of 1922 , entitled 'Manual of Archive Administration', he argues that 'the manner in which archives were created, that is, their natural accumulation during the course of regular activities, as opposed to their having been "singled out for preservation," and their creation and preservation by their creators for their own particular use without consideration as to their future use, endowed archives with the qualities of impartiality and authenticity." (Tschan, 2002, p.3). He also strongly felt that archives were composed of interrelated records, and that it was this contextual whole which imparted meaning and which required preservation. On this basis Jenkinson and his school of thought, felt that the records creator is responsible for determining which records should be transferred to the archives for preservation. In his view records are "impartial," and the task of selection is merely a matter of choosing documents that best describe what happened (Tschan, 2002,p.3).

This school strongly felt it is not in the Archivist's power to appraise records, in that they cannot decide the fate of what they did not create. To Jenkinson "the archivist's chief duty, was the physical and moral defence of the records' integrity, impartiality, authenticity and their resultant "archive value." (Jenkinson, 1922,p.11). The main argument of this school is that the interrelatedness, natural accumulation, uniqueness and the authenticity of archival records would be destroyed is part of the whole is destroyed. They feel that, the context in which they were created and their integrity will also be lost to destruction which will in a way dismember the records. This according to Jenkinson will even be worse if the appraisal of records is put on the hands of archivists. Jenkinson felt that records should be appraised by the creator before they reach the archives and that no further appraisal should be done by archivists. In a nutshell Jenkinson's stand point of appraisal of records was determined by his views as to the nature and purpose of archives, views that

26 The Eastern Librarian-peer-reviewed journal in LIS since 1965 
consistently led him to deny the archivist an active role in the selection of archives or to sanction the destruction of archives after their receipt into archival custody (Tschan, 2002, p.179). Jenkinson argued 'that archives' evidential value arose from their being a direct by-product of administrative activity, and he argued that this evidence should not be corrupted by the intervention of third parties (Honer \& Graham 2001, p.384).

Jenkinson's taxonomy was rubber stamped by the Grigg's Report which ended the haphazard legal position as regards duties of custody and disposal of 'public records' (UK National Archives, 2004, p.1). The report came from an investigation headed by Sir James Grigg. The report supported Jenkinson's ideology in that it gave powers of appraisal to 'reviewers' in government departments with advice and guidance from the UK National Archives (TNA) on how to assess the value of records (as per Schellenberg's approach) as well as to time retention of public records.

However, though Jenkinson's reasoning on appraisal has some valid points based upon the characteristics and purpose of records, there are still some loopholes in it. Firstly, archives as a source of evidence and used for accountability purposes would be exposed to a biased appraisal if selected by the creator. There will be a clash of interest which will result in creators destroying records that reflect bad on them and only transfer those that are 'clean' to archives for permanent preservation. This would therefore, deny the public the benefit of the documentary heritage of an organisation. It would also deny democracy or any system of government and investigation the rule of law due to limitation of credible evidence.

Another downside to Jenkinson's methodology is the failure to address the exponential growth of records. Keeping every record forever was a big ambition by Jenkinson. Maybe one would say his ideology was influenced by the low production of information during the 1920s. Post World War II to today, it has not been possible to think of keeping everything forever due to the technological advancements that influence mass production of information in different formats. This then warrants appraisal of records to takes place every day at personal, corporate and national level and this is so because there are challenges of space (storage room, computers, and servers), equipment and human resource for managing and making accessible the archives to the public. 


\section{THE AMERICAN TAXONOMY OF RECORDS APPRAISAL}

This school of thought was led by Theodore Schellenberg, an Archivists at National Archives and Records Administration (NARA) who is commonly known for his revolutionary writing titled "Modern Archives: Principles and Techniques" published in 1956 (Honer \& Graham 2001, p.384). The theory of appraisal that Schellenberg developed was in response to his environment (accumulation of records after the $2^{\text {nd }}$ World War) thus stressed the need to reduce bulk by selecting from among the masses of documentation those that were permanently valuable, and to make them selection intelligently available to researchers (Tschan, 2002, p.180). Schellenberg felt there is a "practical need of improving governmental efficiency in the face of ever increasing masses of widely scattered documentation" through the process of appraisal. He invented the lifecycle concept and stated that the word archives would only refer to records selected for permanent preservation and the rest would be records management. This created a demarcation of the profession, hence today we have records managers on one hand who manage records in their active and semi-active state and archivists on the other hand handling archives. Atherton (1985, p.43) concurs that the lifecycle has brought some division between archivists and records managers, where "archivists are interested in culture, history, and past events; records managers are concerned with efficiency and the present". Schellenberg argued that records have primary and secondary value. Primary value being the value of the records to the organization itself and to be retained for administrative, financial and legal purposes. And on the other hand secondary value being value of records to the public, possessing research values (informational and evidential). Evidential values provide evidence of the creating organization - its structure, functions, operations and processes, while informational values relate to the information that the records contain (Honer \& Graham 2001, p.385).

Schellenberg complimented his stand on appraisal by arguing that archives should be selected, not only for their value as evidence, but also for their informational content. Unlike Jenkinson who felt creators should appraise records, Schellenberg saw the process of selection as central to the archivist's role (Tschan, 2002,p.177). These two were often placed on opposite ends of the spectrum in terms of their theoretical views, and their ideas and personalities did clash as Jenkinson called Schellenberg's ideas on selection "dangerous"; Schellenberg dismissed Jenkinson as "an old fossil." (Tschan, 2002, p.176).

28 The Eastern Librarian-peer-reviewed journal in LIS since 1965 
However, just like Jenkinson's ideologies, especially on appraisal, there are still some problems associated with the American school of thought. Firstly, Schellenberg's definition of Archives created a rift in the profession through the development of the lifecycle concept of records. Schellenberg's lifecycle concept has undergone more criticism in the last two decades influenced by the proliferation of electronic records which are different in nature and physical form. The criticism of the lifecycle has also been seen with the development of the continuum theory by Ian MacLean who argued that record keeping is a continuing and rolling process that does not separate the life of records in time and space (Upward, 2000). Atherton (1985,p. 47) notes that, the life cycle theory ignores the many ways in which the records management and archives administration operations are interrelated, therefore being a good opportunity for collaboration. He goes on to ask questions 'whether archivists do not have a role in serving creators of the records', 'if they cannot determine disposal periods', and 'if they cannot develop classification schemes'. He also goes on again to ask 'if records managers have no responsibility in identifying records of permanent value or serving researchers'. To me the answer to his question is yes, both archivists and records managers can do these. For example, there is need for collaboration on capture of records as this has a bearing on long term preservation, access and authenticity of a record.

Another problem identified in the American school of thought is that the Archivists are being given too much power by selecting records for permanent preservation on their own without assistance of the creators. Even though Schellenberg was expecting objectivity and professionalism from archivists during appraisal, how would they carry out the exercise without knowing the context in which the records where created in. In this case appraisal would need to be a joint venture between archivists and the creators. Furthermore, how would archivists be able to predict future research needs? It is absolutely impossible to do so. Reflecting on the differences between Jenkinson and Schellenberg appraisal philosophies John Ridener (2009, p. 143-44) observed that, the tension between appraisal and custody, between passive and active archival practice, between history as it happened and communication through historical records is rooted in the discourse between subjectivity and objectivity in archival theory. The tension has never been fully resolved, however, since each new paradigm also assumed many of the concepts of its predecessors, archival theory has accepted each paradigm change cumulatively rather than successively. Theorists today continue to discuss the importance and validity of the discrepancies between Jenkinson and Schellenberg's theories. 


\section{THE GERMAN TAXONOMY OF RECORDS APPRAISAL}

This school was led by Hans Booms who worked as an Archivist at the German Federal Archives in 1955. Just like Schellenberg, his ideology was influenced by the environment he lived in. While post-war Germany had major reorientation in its political, social, and cultural life, according to Booms the archival theory was outdated and needed a new approach (Booms, 1987, p.69). This compelled Booms to develop an alternative to the German archival science of his day, one that was more consistent with the newly introduced democratic principles upon which the German Federal Republic was founded (Booms, 1987, p.69). His approach suggested that creators, users, and custodians of records work together to define and take responsibility for documenting a specific sector of society, the "documentary universe" for a specific organization, group, or activity. Booms's central argument was that society, rather than potential researchers or current administrators, generates the values that define the archival significance, or value, of the records it creates (Booms, 1987, p.69). He centred his approach on the society, hence his ideology on appraisal was named the 'societal model'. Booms differed with Schellenberg suggested that archivists be given absolute power in the selection of permanent records by predicting future research needs. $\mathrm{He}$ called that "archival futurology" which was impossible because it required archivists to be clairvoyants (Tschan, 2002, p.188). To make appraisal decisions, Booms asserted that the archivist must work from a knowledge of the societal framework and values of the records' contemporaries, with the belief that "only the society from which the material originated and for whose sake it is to be preserved can provide archivists with the necessary tools to assess the conceptions by which they bring the past into the present." (Pollard, 2001, p.147). He stressed that archivists should identify a society's values by examining the functions of the records creators themselves, and the relationship between these functions and the records created.

However, Booms approach proved impossible to be practised, which swayed his conclusion on appraisal on provenance, in that "what society deems significant can only be divined "indirectly through research into the functions of those key creators designated by society to realize its needs and wishes." (Tschan, 2002, p.188). His initial plan was to study public opinion polls and the societal dynamics in order to determine what the society viewed as important but this was impossible.

30 The Eastern Librarian-peer-reviewed journal in LIS since 1965 


\section{MACRO- FUNCTIONAL APPRAISAL}

The lead thinker who came up with this methodology of appraisal is Terry Cook, a former Director at National Archives of Canada. This approach to the selection of records is based on the "analysis of the creator's key functions, programmes, activities, and interactions with clients" (Cook, 1997). PearceMoses (2005) defines macro appraisal as "a theory of appraisal that assesses the value of records based on the role of the record creators, placing priority on why the records were created (function), where they were created (structure), and how they were created, rather than content (informational value)". According to Cook, archivists embarking upon appraisals should equip themselves with an understanding of the record creator, its mandate and functions, its structure and decision-making processes, the way it creates records, and changes to these processes over time. The macro-appraisal approach shifted focus to the societal context within which records are created in order to capture those functions, programs, and activities of records creators that interact with and influence society as a whole. Cook placed his appraisal methodology in a context-based, provenance-centred framework rather than in a content-based, historical-documentalist one like the other theorists have done. In macro appraisal provenance is a major focus whereby the contextual circumstances of record creation are made the centre of the archivist's universe of activities, rather than some external criteria such as use, public opinion, or historiographical trends (Cook, 1997). In drawing appraisal decisions in this approach, agencies would first analyze the processes critical to their missions and the tasks required to carry them out, then the selection and evaluation of information used in these activities should reflect the appraised value of the tasks (Cook, 1997). The conclusion that can be drawn from this is that the information/records required and produced from these tasks and transactions are the ones of value for the agencies and ought to be preserved. Beaven (1999, p.158) outlines 3 major advantages of macro-appraisal as (a) "it liberates the archivist from the danger that a priori assumptions about record values may intrude when constructing acquisition or appraisal strategies", (b) "it eliminates the risk of undue preoccupations or prejudices regarding future use or users and (c) "it shifts appraisal from a passive focus on whatever records happen to turn up into a planned, provenance-based focus on records' creational context".

Macro appraisal has been adopted by many archival houses throughout the world and mostly in the Netherlands and Canada (Ramokate \& Moatlhodi, 2010 , p.71). It has been regarded as one of the best approaches on appraisal as

31 The Eastern Librarian-peer-reviewed journal in LIS since 1965 
it centres value of records on the creator's functions. Chebani (2003, p.60) notes that, macro appraisal is more efficient than micro appraisal (analysis at item level) which is more time consuming. Even though macro appraisal is a viable option in the appraisal of records, it may be challenging to apply it in the Southern African context. It can only be applied in jurisdictions where records have been properly managed from their point of creation till deposition where they are properly classified (according to functions of the creator). Setting Botswana as an example, most records are not properly managed because in some public institutions Records Management systems are non-existent and misfiling of records is the order of the day (Ramokate \& Moatlhodi, 2010, p.71). According to Ramokate \& Moatlhodi (2010, p.71) using macro appraisal in this kind of background would be "ineffective and lead to loss of vital information". They recommend adoption of micro appraisal which may be considered time consuming, which may delay access of records to the public. Theoretically, micro-appraisal is designed primarily to validate and refine the hypotheses established earlier about the location of an organization's most important functional activities and most significant records creators (Beaven, 1999, p.155).

Nevertheless, the application of micro appraisal should still take into consideration the 'macro appraisal' values of selection records based on the functions of the creator. So, one could say the choice of approach between micro and macro appraisal would be influenced by the background and level of development of the records management culture of an agency or country. Boomgaard (1994, p. 88) notes that macro appraisal is widely employed in the selection of archives of the municipalities in the Netherlands where records management systems are advanced. Though it has been widely received, macro-appraisal seems to be a bit limited in the appraisal of private papers and records of private organisations (Beaven, 1999, p.159). If there is uncertainty about this, would we see macro-appraisal as the best approach if it doesn't apply to other spheres of records? The argument here is that the theory lacks a component that explains how it can be applicable beyond public records because archives also include records of private individuals and organisations.

\section{THE DOCUMENTATION STRATEGY}

This approach to appraisal was first introduced by Larry Hackman and Helen Samuels in 1984 during the Society of American Archivists annual meeting (Cox, 1996, p.145). The other proponent of this approach is Richard Cox. Documentation strategy is an analytical approach to archival appraisal that 
looks not at individual records, but at the overall universe in which such records exist (Cox, 1996, p.144). It is an on-going, analytic, cooperative approach designed, promoted, and implemented by records creators, administrators (including archivists), and users to ensure the archival retention of appropriate documentation. The key elements in this approach are an analysis of the universe to be documented, an understanding of the inherent documentary problems, and the formulation of a plan to assure the adequate documentation of an issue, activity, or function. The documentary strategy recognizes the problem of volume with modern records that are complex, and tries to provides a platform for records creators, custodians, and users to work together to create a plan for which records will be preserved for future use. The coordination and collaboration of all these stakeholders is key to this approach in deciding retention of records. Just like Booms with his societal model, the documentary strategy differs with Schellenberg who felt the appraisal process is the responsibility archivists alone, but considers input from other stakeholders. Since introduction in 1984, the documentation strategy has met with mixed reactions from the archival profession, and has received its most theoretical examination from the Canadian archival community (Cox, 1996, p. 144). The documentary strategy seems to be difficult to be implemented. Abraham (1995) concurs that, while documentation strategy had its theoretical benefits, it was better as an ideal than it was as a practical guide for the day to day work of the archival repository.

\section{CONCLUSION}

Even in this era faced with explosion of information caused by the technological advancements worldwide resulting in the proliferation of electronic records, appraisal of records continues to be a challenging profession obligation for a contemporary archivist and records manager. The information explosion has also made appraisal more critical because there is need to keep what is of value to both to the organisation and the society it serves. Though the different approaches discussed above have taken a pivotal stage towards exploration of records appraisal, its nature of 'lack of a formula' continues to haunt us. Nevertheless, of all the approaches discussed, macro-appraisal seems to be more convincing and relevant compared to other approaches as it puts the context of records creation at the core of selecting records for permanent preservation. However the ongoing debates at the theoretical level over the years have displayed some form of convergence of these approaches (Beaven, 1999, p.155). One good example is Cook's approval of Boom's selection of

33 The Eastern Librarian-peer-reviewed journal in LIS since 1965 
records based on societal values. He however defends his approach by saying; societal values can be derived from the organisations key functions which would warrant an archivist to have full knowledge of business functions and activities to impose appraisal decisions. Though this paper recommends macro appraisal it is worth noting that it has its own limitations in appraising records of private entities. It is also worth noting that macro-appraisal may not be very effective in situations where records systems are lacking (especially where records were not properly classified) as it may result in loss of vital records. It is therefore, important for records managers and archivists to be part of the process during the development of appraisal standards. Their experience will help theorists in coming up with practical solutions that can be applied during appraisal of records. Beaven (1999, p.154) argues that this should be done through open competition and on a level playing field where real theoretical and operational strengths are fully tested over time.

Beaven (1999, p.155) is correct in asserting that "we cannot afford to leave appraisal standards to the theorists; this is an important sub-text of the foregoing. We endanger our profession if we rely on theoretical debates to determine the scope and direction of the quest for professional standards for appraisal. The ordinary archival practitioner must engage actively in the intellectual debate to define a fully adequate appraisal methodology." Indeed coming up with an adequate appraisal methodology that is flawless is critical. Clear guidance towards records that should provide a reflection of what transpired in the past is also critical. Lack of adequate guidance on appraisal has resulted in 'hit and miss' approach due to the confusion that is there among archivists worldwide. Beaven (1999, p.155) concludes that "if the appraisal function is flawed then the record is flawed and if the record is flawed, the profession will never achieve its strategic ends." These flaws we find in the appraisal exercises also have a negative effect on the public's right to access as the records that they may view as important may be lost to destruction. For many years appraisal has proved to be a challenging but important aspect of the archival profession. Publications of theories have been developed to guide appraisal and the first theory was by Muller, Feith \& Fruin 1898 who came up with the Dutch Manual, then came Jenkinson with Manual of Archives Administration in 1922, Schellenberg with Modern Archives, Booms with the societal model, Cox, Hackman and Samuels with the Documentary Strategy and recently Cook with macro appraisal. As discussed above problems of appraisal have prevailed with these theories in existence. This has been so because there have been problems associated with each one of the theories. It is 
hoped that one day an adequate practical theory will be developed to guide the selection of records for posterity.

\section{REFERENCES}

Abraham, T. (1995). Documentation strategies: A decade (or More) Later. Retrieved from http://www.uiweb.uidaho.edu/special-collections/papers/docstr10.htm

Atherton, J. (1985). From life cycle to continuum: Some thoughts on the records management - Archives relationship. Archivaria 21(2), 43-51.

Beaven, P. (1999). Macro-Appraisal: From theory to practice. Archivaria, 48, 154-198.

Boomgaard, J. (1994). Appraisal and destruction. Janus. Archives Review, 2(1), $88-90$.

Booms, H. (1987). Society and the formation of a documentary heritage: Issues in the appraisal of archival sources. Archivaria, 24(2), 69-107. Retrieved from http://journals.sfu.ca/archivar/index.php/archivaria/article/viewFile/11415/12357

Chebani, B. (2003). The role of reconstructed national archival institutions. MSc Thesis, Aberystwyth: University of Wales.

Cook, T. (1997). What is past is prologue: a history of archival ideas since 1898, and the future paradigm shift. Archivaria, 43(2). Retrieved from http://www.mybestdocs.com/cookt-pastprologue-ar43fnl.htm

Cox, R. (1996). The archival documentation strategy and its implications for the appraisal of architectural records. American Archivist, 59(2), 144-154 Retrieved from http://archivists.metapress.com/content/a63421672782h178/

Daniels, M. (1984). Records appraisal and disposition. managing archives and archival institutions. Chicago: University of Chicago Press.

Honer, E. \& Graham, S. (2001). Should users have a role in determining the future archive? the approach adopted by the public record office, the UK national archive, to the selection of records for permanent preservation. Retrieved from http://liber.library.uu.nl/publish/articles/000449/article.pdf

Jenkinson, H. (1922). A manual of archive administration. Retrieved from http://ia700305.us.archive.org/11/items/manualofarchivea00jenk/manualofarch ivea00jenk.pdf

Menne-Haritz, A. (1997). Framework and aims of appraisal. Paris: International Council on Archives.

Nicol, A. (1992). Ethics of appraisal. Janus: Archival Review, 2. Paris: International Council on Archives.

Pearce-Moses, R. (2005). A glossary of archival and records terminology. Retrieved from http://www.archivists.org/glossary/term_details.asp?DefinitionKey=224

Pollard, R. (2001). The Appraisal of Personal Papers: A Critical Literature Review. Archivaria, 52(1). 
Ramokate, K. \& Moatlhodi, T. (2010). Battling the appraisal backlog: A challenging professional obligation for Botswana National Archives and Records Services (BNARS). ESARBICA Journal, 29, 67-86.

Ridner, J. (2009). From polders to post-modernism. Duluth: Litwin Books.

Schellenberg, T. (1956). Modern archives: principles and techniques. Chicago:University of Chicago Press.

Schellenberg, T. (1956). The appraisal of modern public records. Bulletins of the National Archives, Number 8. Washington: US Government Printing.

Tschan, R. (2002). A comparison of jenkinson and schellenberg on appraisal. Retrieved from http://archivists.metapress.com/content/920w65g321770611/

UK National Archives. (2004). The 'Grigg system' and beyond. Retrieved from http://www.nationalarchives.gov.uk/documents/informationmanagement/background_appraisal.pdf

University of British Columbia. (2005). Archival terminology. Retrieved from http://www.slais.ubc.ca/resources/students/Archival_Terminology.pdf

Upward, F. (1996). Structuring records continuum - part one: post custodial principles and properties. Archives and Manucscripts, 24(2). Retrieved from http://infotech.monash.edu/research/groups/rcrg/publications/recordscontinuu m-fupp1.html

Yiotis, K. (2005). Two theories of appraisal: cook and duranti. structuring records continuum - part one: post custodial principles and properties. Retrieved from http://kristinhome.com/eportfolio/a/256ArchivesEssay2.pdf 